\section{Response of Plasticultured Bell Pepper to Staking, Irrigation Frequency, and Fertigated Nitrogen Rate}

\author{
Pat Bowen \\ Pacific Agri-Food Research Centre, 4200 Highway 97, Summerland, BC, V0H \\ 1Z0, Canada

\section{Brenda Frey \\ Pacific Agri-Food Research Centre, P.O. Box 1000, Agassiz, BC, V0M 1A0, Canada}

Additional index words. Capsicum annuum, mini-tunnel, drip irrigation, plastic mulch, stake, dry matter partitioning

\begin{abstract}
Effects of staking, drip irrigation frequency and fertigated $\mathrm{N}$ rate on dry matter partitioning and yield of bell peppers (Capsicum annuum L.), grown using polyethylene mulch and mini-tunnels, were determined in two years. In the second year, which had higher early-season temperatures and more hours of direct sunlight, plants were larger, more productive and had larger fruit with thicker pericarps and a higher water content than in the first year. In both years, staked plants fertigated with $31.5 \mathrm{vs} .63 \mathrm{~kg} \cdot \mathrm{ha}^{-1} \mathrm{~N}$ produced higher yields due to increased fruit size and pericarp thickness. Compared with the response to monthly irrigation plus rainfall, additional irrigation applied when the soil moisture tension averaged below -25 and $-20 \mathrm{kPa}$ in the two years, respectively, affected yield only in the second year when it increased yield and the number of fruits produced by staked plants and decreased that of non-staked plants. Patterns of vegetative development and dry matter partitioning indicate that resources were remobilized from leaves to support fruit development.
\end{abstract}

Early and total yields of bell peppers can be increased with plastic mini-tunnels used early in the growing season (Alexander and Clough, 1998; Gaye et al., 1992a, 1992b; Wells and Loy, 1985). This improved crop performance has been attributed to the higher-than-ambient tunnel air temperatures contributing to accelerated plant growth and development (Gerber et al., 1988; Maurer and Frey, 1987). Another possible benefit of mini-tunnels is the shielding of plants from wind which induces stomatal closure and disturbs leaf display. In a study of the effects of a windbreak on peppers, protected plants were found to be larger and produce more or larger fruits (Monette and Stewart, 1987).

In commercial pepper production, minitunnels are removed in midseason before tunnel air temperatures get so high as to cause plant stress. However, this sudden exposure of plants to wind often increases the drooping of fruit-laden branches, which reduces the light exposure of some leaves and fruit while increasing that of others. The degree to which this change in structure and exposure alters the developmental processes involved in fruit production, such as water relations, $\mathrm{N}$ utilization and dry matter partitioning, is not known. If branches are maintained in an upright position, then light exposure may not be disrupted.

Received for publication 11 Jan. 2001. Accepted for publication 12 Apr. 2001. We thank David Ehret and Grant Kowalenko for reviewing the manuscript, and Agriculture and Agri-Food Canada for the financial support of this study.
The effect of staking on pepper production and how this practice particularly affects peppers grown initially in mini-tunnels are not well understood. In this study, the effects on yield and plant dry matter partitioning of staking to maintain plant structure after mini-tunnel removal were examined on plants grown under different irrigation and $\mathrm{N}$ fertigation regimes.

\section{Materials and Methods}

Two experiments were conducted in 1991 and 1992 at adjacent sites in the same field at Agassiz, B.C., Canada. The soil is a Monroe silt loam with $5.5 \%$ to $5.8 \%$ organic matter, classified as a Eutric Eluviated Brunisol. In the year before each planting, dairy manure was applied in the spring and a rye cover crop was seeded in mid-summer and incorporated by ploughing the following April. In south-coastal British Columbia, $\approx 1000 \mathrm{~mm}$ of water from rainfall percolates through the soil profile in the fall and winter (Zebarth et al., 1995), leaching all nitrate- $\mathrm{N}$ from the soil rooting zone (Kowalenko, 1987). Soil samples taken in March in each planting year contained 7-8 $\mathrm{g} \cdot \mathrm{mL}^{-1}$ extractable nitrate. Net $\mathrm{N}$ mineralization rate to $0.75-\mathrm{m}$ depth in a similar but nonmulched soil at the same site varied from 0 to $1.0 \mathrm{~kg} \cdot \mathrm{ha}^{-1} /$ day of $\mathrm{N}$ during the growing season (Kowalenko, 1987).

Treatments were a factorial combination of two drip irrigation frequencies, two $\mathrm{N}$ fertigation rates $\left(31.5\right.$ and $63 \mathrm{~kg} \cdot \mathrm{ha}^{-1}$ total $\mathrm{N}$ per year), and plants cultured with and without staking. The eight treatments were applied in a split-plot design replicated in four blocks. Irrigation frequency and $\mathrm{N}$ fertigation treatments were applied to main plots and staking was applied to subplots. Each subplot was a section of raised bed with two rows of plants. In the first year subplots had 14 plants and were $3.15 \mathrm{~m}$ long, and in the second year they had 18 plants and were $4.05 \mathrm{~m}$ long.

The field was prepared each year for transplanting by cultivation followed by the formation of raised beds that were $0.25 \mathrm{~m}$ high $\times 1.1 \mathrm{~m}$ wide and $1.8 \mathrm{~m}$ apart from center to center. A single line of drip irrigation tape (Typhoon 06-T20-.4; Netafim, Fresno, Calif.) was laid at the center of the beds before $1.5 \mathrm{~m}$ wide green polyethylene mulch (IRT-76; AEP Industries, South Hackensack, N.J.) was applied using a tractor-drawn applicator. The lateral irrigation line for each main plot treatment was connected to a valve manifold operated to selectively control the application of water and injected fertilizers.

'Bell Boy' pepper transplants were grown for 6 weeks in the greenhouse in trays with $100-\mathrm{mL}$ cells. Transplanting was on 17 May 1991 and 13 May 1992. The plants were spaced $0.45 \mathrm{~m}$ apart within two staggered rows $0.45 \mathrm{~m}$ apart in each bed. For plants that were staked, 0.6-m-long bamboo stakes were inserted into the ground to a depth of $0.3 \mathrm{~m}$ next to each plant immediately after planting. Plant main stems were loosely attached to the stakes with twist-ties. All planted beds were then covered with a $2-\mathrm{mL}$ clear polyethylene mini-tunnels supported by 0.8 -m-tall wire hoops spaced $2 \mathrm{~m}$ apart. The tunnels were ventilated with two rows, $15 \mathrm{~cm}$ apart, of $15-\mathrm{cm}$ slits spaced 1.5 $\mathrm{cm}$ apart. Starting in mid-June, ventilation was increased by raising the lower edge of one side of the tunnels $30 \mathrm{~cm}$ at every second hoop. The tunnels were removed in mid-July. On the day of tunnel removal, the branches of staked plants were supported in place along the outsides of the beds with nylon string attached $50 \mathrm{~cm}$ from the ground to bamboo stakes $1.5 \mathrm{~m}$ apart.

Fertilizer was applied through the drip irrigation system (fertigated) monthly according to the schedule in Table 1. Application of 31.5 $\mathrm{kg} \cdot \mathrm{ha}^{-1}$ total $\mathrm{N}$ was achieved by applying $\mathrm{NH}_{4} \mathrm{NO}_{3}$ to supply $1.70 \mathrm{~kg} \cdot \mathrm{ha}^{-1} \mathrm{~N}$ within a week of transplanting then alternating monthly rates to supply 4.25 and $8.50 \mathrm{~kg} \cdot \mathrm{ha}^{-1} \mathrm{~N}$, with the lower rate applied when $\mathrm{MgSO}_{4}, \mathrm{ZnSO}_{4}$, and Solubor (U.S. Borax, Valencia, Calif.) were applied concurrently. The $\mathrm{NH}_{4} \mathrm{NO}_{3}$ rates were doubled for the $63.0 \mathrm{~kg} \cdot \mathrm{ha}^{-1}$ total $\mathrm{N}$ treatment. Soil matric potential was measured twice weekly at a depth of 21-24 cm midway between two plants in a row in each subplot, using a tensiometer capped with a rubber serum stopper and measured using a Tensimeter (Soil Measurement Systems, Tucson, Ariz.) pressure sensor. Plots receiving high frequency (HF) irrigation were irrigated when the average soil matric potential measured was less than $-25 \mathrm{kPa}$ in the first year and $-20 \mathrm{kPa}$ in the second year. Plots receiving low frequency (LF) irrigation were irrigated monthly when fertilizers were applied (Figs. 1 and 2), except during the first 6 weeks after planting in 1992, when air temperatures 
Table 1. Fertigation schedule for peppers under two $\mathrm{N}$ fertilization regimes.

\begin{tabular}{|c|c|c|c|c|c|c|}
\hline \multirow{2}{*}{$\begin{array}{l}\text { Fertilizer } \\
\text { source and } \\
\text { nutrient } \\
\text { element }\end{array}$} & \multicolumn{6}{|c|}{ Date } \\
\hline & $\begin{array}{l}19 \text { May 1991; } \\
21 \text { May } 1992 \\
\end{array}$ & $\begin{array}{l}1 \text { June } 1991 ; \\
31 \text { May } 1991 \\
\end{array}$ & $\begin{array}{l}2 \text { July } 1991 ; \\
2 \text { July } 1992 \\
\end{array}$ & $\begin{array}{l}\text { 1 Aug. 1991; } \\
5 \text { Aug. 1992 }\end{array}$ & $\begin{array}{l}3 \text { Sept. 1991; } \\
3 \text { Sept. } 1992 \\
\end{array}$ & $\begin{array}{l}1 \text { Oct. } 1991 ; \\
8 \text { Oct. } 1992 \\
\end{array}$ \\
\hline \multicolumn{7}{|c|}{ Application rate of nutrient element $\left(\mathrm{kg} \cdot \mathrm{ha^{-1 }}\right)$} \\
\hline$\underset{\mathrm{K}}{\mathrm{KH}_{2} \mathrm{PO}_{4}}$ & 8.13 & 17 & 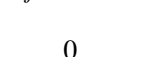 & 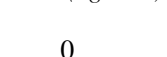 & 0 & 0 \\
\hline $\mathrm{P}$ & 3.22 & 0 & 0 & 0 & 0 & 0 \\
\hline \multicolumn{7}{|l|}{$\mathrm{MgSO}_{4}$} \\
\hline $\mathrm{Mg}$ & 0 & 7.47 & 0 & 7.47 & 0 & 7.47 \\
\hline $\mathrm{S}$ & 0 & 9.85 & 0 & 9.85 & 0 & 9.85 \\
\hline \multicolumn{7}{|l|}{$\mathrm{ZnSO}_{4}$} \\
\hline $\mathrm{Zn}$ & 0 & 0.29 & 0 & 0.29 & 0 & 0.29 \\
\hline S & 0 & 0.14 & 0 & 0.14 & 0 & 0.14 \\
\hline \multicolumn{7}{|l|}{ Solubor } \\
\hline B & 0 & 0.10 & 0 & 0.10 & 0 & 0.10 \\
\hline \multicolumn{7}{|c|}{$\begin{array}{l}\mathrm{NH}_{4} \mathrm{NO}_{3} \\
\quad \mathrm{~N} \text {, total rate }\left(\mathrm{kg} \cdot \mathrm{ha}^{-1}\right)\end{array}$} \\
\hline 31.5 & 1.70 & 4.25 & 8.50 & 4.25 & 8.50 & 4.25 \\
\hline 63.0 & 3.40 & 8.50 & 17.0 & 8.50 & 17.0 & 8.50 \\
\hline
\end{tabular}

were unseasonably high and the young plants showed signs of stress. During this period, irrigation was applied to plots receiving LF irrigation when the measurements averaged below $-50 \mathrm{kPa}$. All irrigations were for $1.5 \mathrm{~h}$ to provide $7.5 \mathrm{~L}$ of water per meter of bed, from emitters $30 \mathrm{~cm}$ apart. All plots received additional water from rain.

Flowers on two plants per subplot were counted weekly and their corollas marked with a water-proof felt marker to avoid recounting the same flowers in the following week. Aboveground vegetative growth characteristics were determined from one plant, surrounded by guard plants, removed from each subplot every 8 weeks. These plants were partitioned into leaves and stems. The leaves were counted and their total area was measured using an area meter (LI-3000; LI-COR, Lincoln, Nebr.). The total dry weights of leaf and stem tissues were measured after they were oven-dried for $2 \mathrm{~d}$ at $60^{\circ} \mathrm{C}$. The total dry weight of immature fruit was also measured in the final plant harvest.

Red-ripe fruits were harvested at weekly intervals starting in late August in the first year, and in mid-September in the second year. Harvests continued through October in both years. At each harvest, the weight and number of fruits were determined separately for those marketable $(\geq 100 \mathrm{~g})$ and undersized $(<100 \mathrm{~g})$. Pericarp thickness, lobe number, and fruit diameter and length were determined for three marketable fruits selected at random from each subplot harvest. Pericarp thickness was measured at two locations midway between fruit septa and between the base (calyx end) and top of the fruit.

Ambient air temperature, rainfall and direct sunlight measurements were obtained from a weather station (Agassiz CDA; Environment Canada, Ottawa, Ont.) located $\approx 100 \mathrm{~m}$ from the study site. Treatment effects on all plant response variables were analyzed using analysis of variance for a split plot design. Data from the two experiments were analyzed separately because of the small difference in the HF irrigation treatment thresholds in the two years. 1992 resulted in mild wilting of the young measured was below $-25 \mathrm{kPa}$. Vertical bars are $\pm \mathrm{SE}$. plants in plots receiving LF irrigation, which was eliminated by irrigating at $-50 \mathrm{kPa}$. $\mathrm{Au}-$ gust had more rainfall than average in 1991, but was followed by an unusually dry September and October. The air temperature, hours of direct sunlight, and amount of precipitation in late Summer and Fall 1992 were near average for the region. LF irrigations were applied six times in 1991 and nine times in 1992. HF irrigations were applied 18 times in 1991 and 20 times in 1992.

Higher ambient temperatures and more hours of direct sunlight in the first 8 weeks of 1992 (Fig. 2), compared with 1991 (Fig. 1), were coincident with greater increases in leaf and stem dry weights and the number and total area of leaves across all treatments (Fig. 3). This period was followed by similar midseason weather in the two years, then warmer and sunnier late-season weather in 1991 than in 1992. Although it appears that there was better leaf retention in the final 8 weeks of 1991 than in 1992, measurements of vegetative growth remained higher through most of the 1992 growing season.

Treatment effects on vegetative development differed between the two years and were small compared with the apparent effect of climate in the first 8 weeks. In 1991, staking increased leaf initiation in midseason, resulting in $8 \%$ more leaves at 16 weeks from planting (Fig. 3). However, these additional leaves were small since they had no significant effect on total leaf area or dry weight. After a

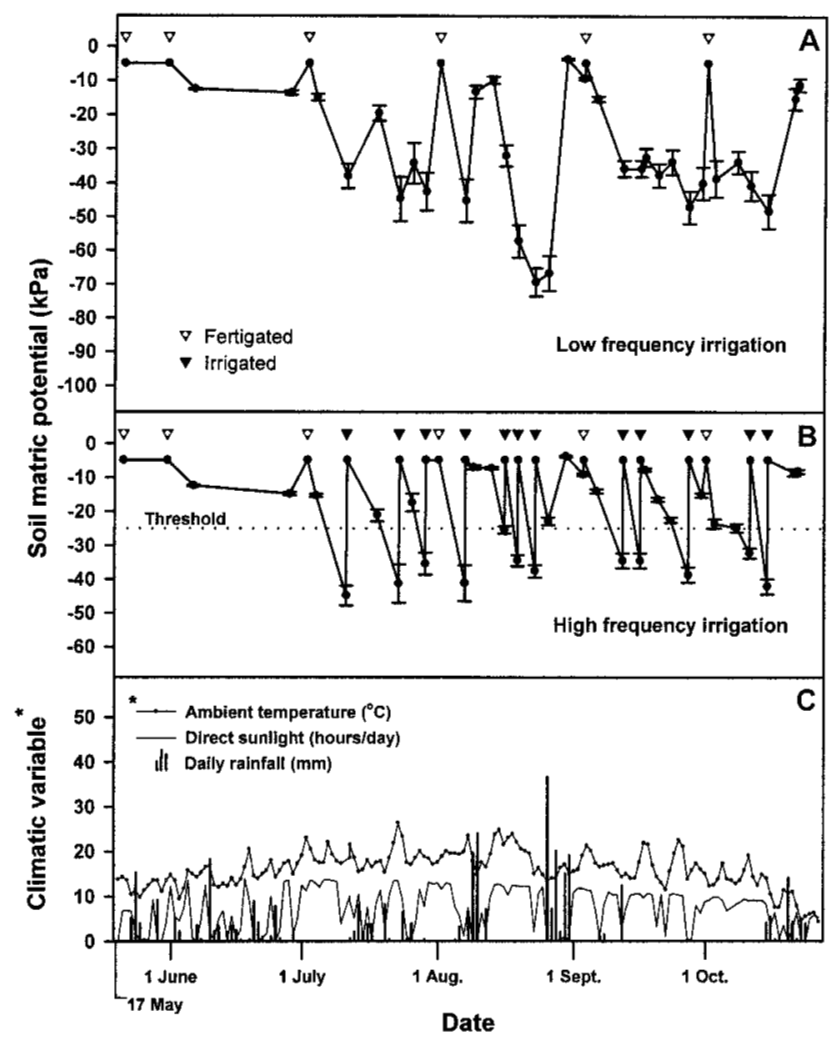

Fig. 1. Soil matric potential at $21-24 \mathrm{~cm}$ depth midway between plants in the crop row measured in response to (A) low frequency (LF) irrigation and (B) high frequency (HF) irrigation; (C) and climatic characteristics during the growing season in 1991. LF irrigation was applied at monthly fertigations. HF irrigation was applied additionally between fertigations when the average soil matric potential 


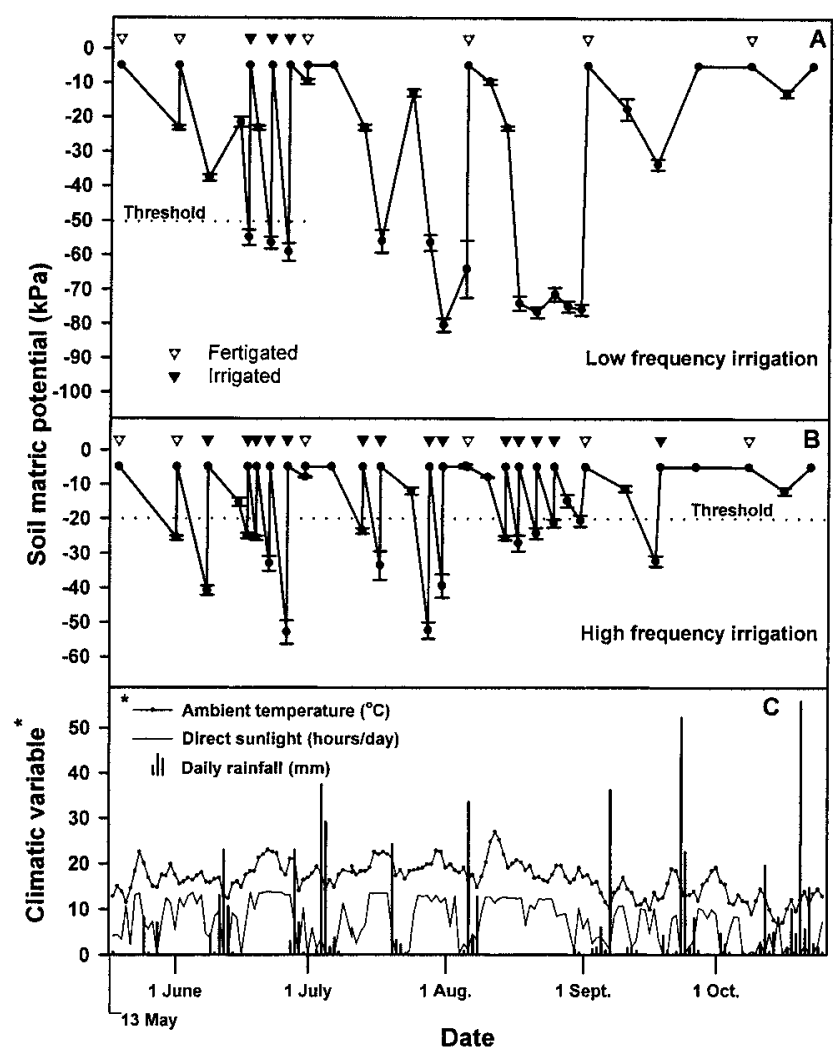

Fig. 2. Soil matric potential at 21-24 cm depth midway between plants in the crop row measured in response to (A) low frequency (LF) irrigation and (B) high frequency (HF) irrigation; and (C) climatic characteristics during the growing season in 1992. LF irrigation was applied at monthly fertigations. HF irrigation was applied between fertigations when the average soil matric potential measured was below $-20 \mathrm{kPa}$. To prevent wilting during plant establishment, three irrigations were applied in July to plots receiving LF irrigation when the average soil matric potential measured was below -50 $\mathrm{kPa}$. Vertical bars are $\pm \mathrm{SE}$.

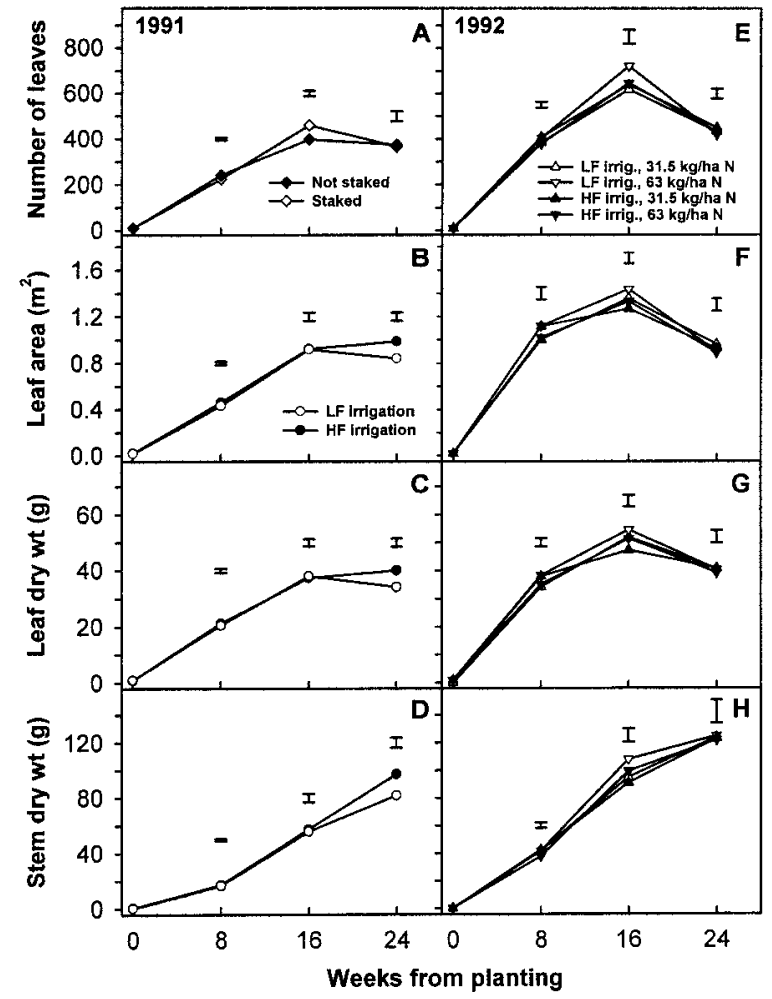

Fig. 3. Vegetative growth characteristics, per plant, affected significantly $(P$ $<0.05)$ by nitrogen, staking, or irrigation treatments or their interactions. In 1991 (A-D), the number of leaves (A) was affected by staking, and leaf area $(\mathbf{B})$ and the dry weights of leaves and stems (C and $\mathbf{D}$, respectively) were affected by irrigation. In 1992 (E-H), all characteristics were affected by the interaction of nitrogen and irrigation. LF irrig. and HF irrig. refer to low and high frequency irrigation, respectively. Vertical bars are pooled SE. period of leaf abscission in the final 8 weeks, plants with and without stakes had equal numbers of leaves.

Although LF irrigation resulted in soil matric potentials below $-40 \mathrm{kPa}$ at $21-24 \mathrm{~cm}$ depth within the crop row several times in both growing seasons (Figs. 1 and 2), more frequent irrigation had little effect on vegetative development. It increased leaf area and dry weight and stem dry weight only in the final 8 weeks of the 1991 growing season (Fig. 3). This indicates either that pepper vegetative development is not strongly influenced by such low soil moisture levels, or that the crop accessed moister soil deeper in the profile or outside the crop row. Rainfall often significantly increased the soil moisture levels measured in the crop row, and may have provided substantial water outside the crop row, which continued to be accessed by the crop roots when in-row moisture was depleted. This non-irrigation supply of water may have been depleted when there was little rainfall in the final weeks of the 1991 growing season, so vegetative development responded to additional irrigation.

In 1992, vegetative growth measurements were higher by 16 weeks after planting when the higher $\mathrm{N}$ rate was applied together with LF irrigation (Fig. 3). This may indicate that the high crop growth rate early in 1992 depleted soil $\mathrm{N}$ to levels that limited growth, and less frequent irrigation may have prevented or reduced $\mathrm{N}$ leaching or heat loss from the root zone. After significant loss of leaves in the final 8 weeks of the 1992 season, there were no treatment differences in measured vegetative characteristics.

Total dry matter produced per plant was similar in the two years (Table 2). The total dry weight of marketable $(\geq 100 \mathrm{~g})$ fruit was also similar in the two years, but it appears that there was more dry matter in immature and undersized $(<100 \mathrm{~g})$ mature fruit in 1991 than in 1992. The mean percentage of total dry matter partitioned to fruit was $61 \%$ in 1991 , which was similar to that found by Leskovar and Cantliffe (1993), and 49\% in 1992. In both years, staking reduced the total dry weight of undersized fruit and increased that of marketable fruit when the lower $\mathrm{N}$ rate was applied. In 1991, marketable fruit dry weight was increased more by staking when LF irrigation was applied, but in 1992 staking increased marketable fruit dry weight only when HF irrigation was applied. Other studies with irrigation treatments that supplemented rainfall have also found inconsistent or no effect on pepper production (Batal and Smittle, 1981; Haynes and Herring, 1981; O'Sullivan, 1979; VanDerwerken and Wilcox-Lee, 1988).
It appears that fresh fruit yields were higher in 1992, due to more, larger, and heavier fruits with thicker pericarps and a higher moisture content (Tables 3 and 4). These fruit characteristics did not respond to more frequent irrigation in1991, indicating that fruit development was not limited by soil moisture supply. Fruit development and moisture accumulation may have been enhanced by the larger leaf canopies in 1992 than in 1991. Reducing the exposure of developing pepper fruits to direct sunlight has been shown to increase fruit size (Rylski and Spigelman, 1986).

Despite the apparent overall differences in vegetative development and yield between the two years, yield response to staking and $\mathrm{N}$ fertigation rate was consistent and similar to that of fruit dry weight. In 1991, total and marketable yields and the number of marketable fruit were improved with staking, and more so when 31.5 rather than $63 \mathrm{~kg} \cdot \mathrm{ha}^{-1} \mathrm{~N}$ was applied (Table 3). In 1992, these yield characteristics were improved with staking only when the lower $\mathrm{N}$ rate or more frequent irrigation was applied. In both years staking increased the length, pericarp thickness and individual weight of marketable fruits (Tables 3 and 4). Staking also increased fruit diameter in 1992, and in 1991 when HF irrigation was applied. Staking alone and in combination 
Table 2. Partitioning of dry matter per pepper plant in response to nitrogen fertilizer, irrigation frequency, and staking.

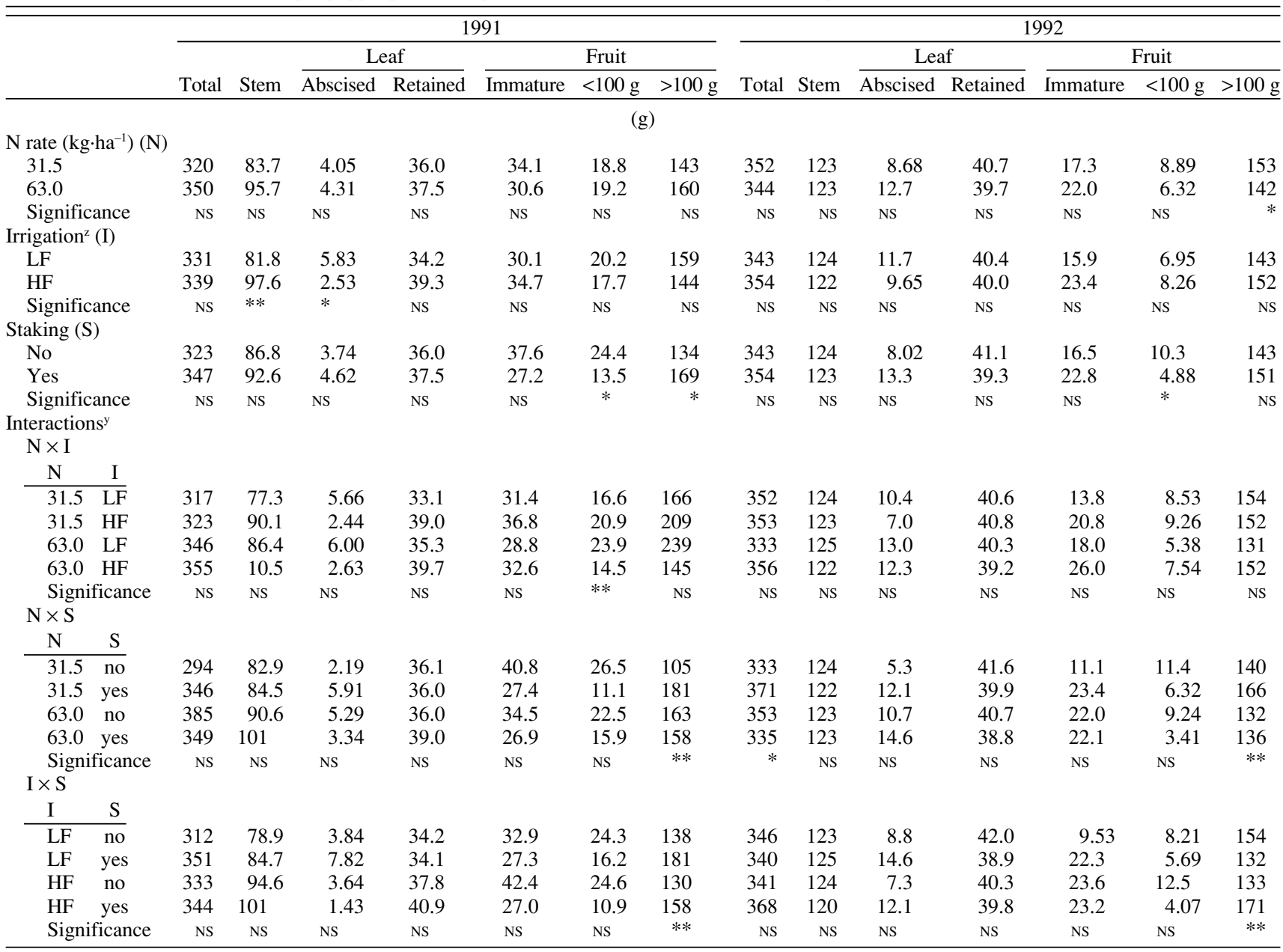

${ }^{2}$ Irrigation frequency: LF = low frequency; HF = high frequency.

${ }^{y} \mathrm{~N} \times \mathrm{S} \times$ I interactions were all nonsignificant and are not shown.

Ns, ${ }^{*}, * *$ Nonsignificant or significant at $P<0.05$ or 0.01 , respectively.

with other treatments that improved yield and quality characteristics did not increase the number flowers produced in the first two or four weeks, or the total number of fruits per plant (Table 3). These results indicate that staking enhanced fruit development but not flowering or set. The reduction in flowers produced later in the season in response to less $\mathrm{N}$ applied to staked plants may have resulted from a suppression of flowering by the higher crop load.

The lack of a positive yield response to increasing $\mathrm{N}$ fertigation from 31.5 to 63 $\mathrm{kg} \cdot \mathrm{ha}^{-1} \mathrm{~N}$ is consistent with several other studies that found peppers require low $\mathrm{N}$ fertilization rates for near maximum production (Carballo et al., 1994; Clark and Stanley, 1998; Hartz et al., 1993; Locascio and Stall, 1994; Madramootoo and Rigby, 1991; O'Sullivan, 1979; Qawasmi et al., 1999; Russo, 1991; Thomas and Heilman, 1964; Wiedenfeld, 1979). However, it is unclear why staked plants were more productive when fertigated with the lower $\mathrm{N}$ rate. Competition for resources between fruit development and $\mathrm{N}$-stimulated vegetative growth was not likely involved because additional $\mathrm{N}$ increased vegetative growth only in 1992 and regardless of staking (Fig. 3). Staking may have helped to maintain favorable leaf orientation for light interception, increasing photosynthesis and carbon available to developing fruit. Although $\mathrm{N}$ nutrition is important for these processes (Hedge, 1987), excess soluble $\mathrm{N}$ in the soil can increase soil osmotic potential to levels that lower leaf water potential, reducing stomatal conductance and carbon assimilation. Previous reports indicate that pepper plants may be particularly sensitive to excess soil N. Yield reductions in response to increasing $\mathrm{N}$ fertilization have been reported for rates in excess of, in $\mathrm{kg} \cdot \mathrm{ha}^{-1}, 70$ (O'Sullivan, 1979), 120 (Thomas and Heilman, 1964), 150 (Qawasmi et al., 1999), 168 (Hartz et al., 1993), 210 (Hochmuth et al., 1987), 240 (Payero et al., 1990), and 300 (Crespo-Ruiz et al., 1988). This detrimental effect of excess $\mathrm{N}$ has been attributed to elevated soil electrical conductivity or salt levels (Hochmuth et al., 1987; Qawasmi et al., 1999), and was found to be enhanced by reduced irrigation (Hochmuth et al., 1987). Although sensitivity to elevated salt levels would explain the reduction in yield from applying additional $\mathrm{N}$ to staked plants, yield of plants not staked was generally improved by additional $\mathrm{N}$ (Table 3 ). This suggests that staking may affect plant $\mathrm{N}$ utilization, water relations or other physiological processes that involve $\mathrm{N}$ supply and influence fruit development.

About half of the total $\mathrm{N}$ taken up by pepper plants is partitioned to fruit (Locascio et al., 1985; Miller et al., 1979; Olsen et. al., 1993). The coincidence of leaf abscission with fruit enlargement in the final weeks, especially in 1992 , indicates that pepper is similar to other crops that remobilize leaf $\mathrm{N}$ to support the lateseason, rapid development of tissues or organs such as flowering heads in broccoli (Brassica oleracea var. italica) (Bowen et al., 1999) and buds in brussels sprouts (Brassica oleracea var. gemmifera) (Booij and Meurs, 1994). Pepper leaf $\mathrm{N}$ has been found to decrease during fruit enlargement, even when $\mathrm{N}$ fertilizer was applied at rates that maximize yield (Hartz et al., 1993; Miller et al., 1979; Thomas and Heilman,1964). These results indicate that leaf $\mathrm{N}$ may be the primary source of $\mathrm{N}$ used in pepper fruit development. In this study, the higher number of leaves and greater total leaf area resulting from the higher rate of early plant growth in 1992 than in 1991 was coincident with enhanced fruit development. This may be because the leaf canopy was not only a source of $\mathrm{C}$ but a source of shade and remobilized $\mathrm{N}$ for developing fruit. Staking 
Table 3. Flowering, fruit yield, and fruit number per plant, and weight of fruits in response to nitrogen fertilizer, irrigation frequency, and staking.

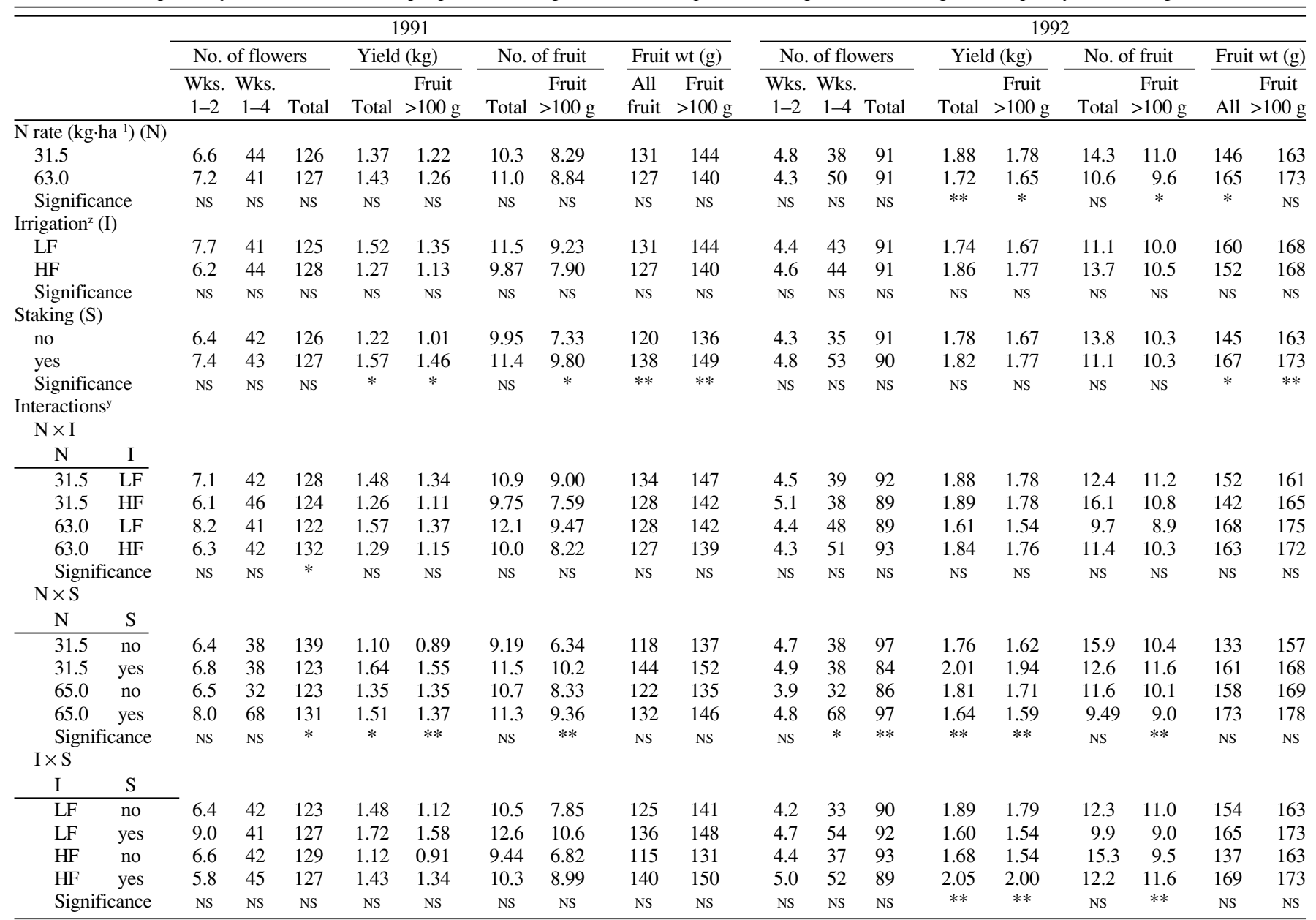

Irrigation frequency: $\mathrm{LF}=$ low frequency; $\mathrm{HF}=$ high frequency.

${ }^{y} \mathrm{~N} \times \mathrm{S} \times \mathrm{I}$ interactions were all nonsignificant and are not shown.

Ns, *,** Nonsignificant or significant at $P<0.05$ or 0.01 , respectively.

pepper plants to maintain canopy structure after mini-tunnel removal appears to enhance fruit development and quality, but its effect on yield can depend on the supply of $\mathrm{N}$ and water.

\section{Literature Cited}

Alexander, S.E. and G.H.Clough. 1998. Spunbonded rowcovers and calcium fertilization improve quality and yield in bell pepper. HortScience 33:1150-1152.

Batal, K.M. and D.A. Smittle. 1981. Response of bell pepper to irrigation, nitrogen and plant population. J. Amer. Soc. Hort. Sci. 106:259-262.

Booij, R. and B. Meurs. 1994. C and N fluxes in brussels sprouts (Brassica oleracea var. gemmifera) during bud development. HortScience 29:473. (Abstr.)

Bowen, P.A., B.J. Zebarth, and P.M.A. Toivonen. 1999. Dynamics of nitrogen and dry matter partitioning and accumulation in broccoli (Brassica oleracea var. italica) in relation to extractable soil inorganic nitrogen. Can. J. Plant Sci. 79:277-286.

Carballo, S.J., S.M. Blankenship, and D.C. Sanders. 1994. Drip fertigation with nitrogen and potassium and postharvest susceptibility to bacterial soft rot of bell peppers. J. Plant Nutr. 17:11751191.

Clark, G.A. and C.D. Stanley. 1998. MSWC as a soil amendment in irrigated vegetable production. Presented at 1998 ASAE Annu. Intl. Mtg., Orlando, Fla.
Crespo-Ruiz, M., M.R. Goyal, C. Chao de Baez, and L.E. Rivera. 1988. Nutrient uptake and growth characteristics of nitrogen fertigated sweet peppers under drip irrigation and plastic mulch. I. Agr. Univ. Puerto Rico. 72:575-584.

Gaye, M.M., G.W. Eaton, and P.A. Jolliffe. 1992a. Row covers and plant architecture influence development and spacial distribution of bell pepper fruit. HortScience 27:397-399.

Gaye, M.M., P.A. Jolliffe, and A.R. Maurer. 1992b. Row cover and population density effects on yield of bell peppers in south coastal British Columbia. Can. J. Plant Sci. 72:901-909.

Gerber, J.M., I. Mohd-Khir, and W.E. Splittstoesser. 1988. Row tunnel effects on yield and fruit quality of bell pepper. Scientia Hortic. 36: 191197.

Hartz, T.K., M. LeStrange, and D.M. May. 1993. Nitrogen requirements of drip-irrigated peppers. HortScience 28:1097-1099.

Haynes R. and S. Herring. 1981. Performance of drip irrigated bell peppers. Arkansas Farm Res. 30:12.

Hedge, D.M. 1987. Growth analysis of bell pepper (Capsicum annuum L.) in relation to soil moisture and nitrogen fertilization. Scientia Hort. 33:179-187.

Hochmuth, G.J., K.D. Shuler, R.L. Mitchell, and P.R. Gilreath. 1987. Nitrogen crop nutrient requirement demonstrations for mulched pepper in Florida. Proc. Fla. State Hort. Soc. 100:205209.
Kowalenko, C.G. 1987. The dynamics of inorganic nitrogen in a Fraser Valley soil with and without spring or fall ammonium nitrate applications. Can. J. Soil Sci. 67:367-382.

Leskovar, D.I.. and D.J. Cantliffe. 1993. Comparison of plant establishment method, transplant, or direct seeding on growth and yield of bell pepper. J. Amer. Soc. Hort. Sci. 118:17-22.

Locascio, S.J., J.G.A. Fiskel, D.A. Graetz, and R.D. Hauck. 1985. Nitrogen accumulation by pepper as influenced by mulch and time of fertilizer application. J. Amer. Soc. Hort. Sci. 110:325328.

Locascio, S.J. and W.M. Stall. 1994. Bell pepper yield as influenced by plant spacing and row arrangement. J. Amer. Soc. Hort. Sci. 119:899902.

Madramootoo, C.A. and M. Rigby. 1991. Effects of trickle irrigation on the growth and sunscald of bell peppers (Capsicum annuum L.) in southern Quebec. Agr. Water Mgt. 19:181-189.

Maurer, A.R. and B.M. Frey. 1987. Response of bell peppers to row covers. Agriculture and AgriFood Canada, Pacific Agri-Food Research Centre, Agassiz Tech. Rpt. 31.

Miller, C.H., R.E. McCollum, and S. Claimon. 1979. Relationship between growth of bell peppers (Capsicum annuum L.) and nutrient accumulation during ontogeny in field environments. J. Amer. Soc. Hort. Sci. 104:852-857.

Monette, S. and K.A. Stewart. 1987. The effects of a windbreak and mulch on the growth and yield 


\section{Crop Production}

Table 4. Pepper fruit quality characteristics in response to nitrogen fertilizer, irrigation frequency and staking.

\begin{tabular}{|c|c|c|c|c|c|c|c|c|c|}
\hline & & \multicolumn{4}{|c|}{1991} & \multicolumn{4}{|c|}{1992} \\
\hline & & $\begin{array}{l}\text { Length } \\
(\mathrm{cm})\end{array}$ & $\begin{array}{l}\text { Diam } \\
(\mathrm{cm})\end{array}$ & $\begin{array}{c}\text { Pericarp } \\
\text { thickness }(\mathrm{mm})\end{array}$ & $\begin{array}{c}\text { Moisture } \\
(\%)\end{array}$ & $\begin{array}{l}\text { Length } \\
(\mathrm{cm})\end{array}$ & $\begin{array}{c}\text { Diam } \\
(\mathrm{cm})\end{array}$ & $\begin{array}{c}\text { Pericarp } \\
\text { thickness }(\mathrm{mm})\end{array}$ & $\begin{array}{c}\text { Moisture } \\
(\%)\end{array}$ \\
\hline \multicolumn{10}{|c|}{$\mathrm{N}$ rate $\left(\mathrm{kg} \cdot \mathrm{ha}^{-1}\right)(\mathrm{N})$} \\
\hline 31.5 & & 8.22 & 6.75 & 5.28 & 88.1 & 8.33 & 7.95 & 5.86 & 91.6 \\
\hline 63.0 & & 7.69 & 6.52 & 5.23 & 90.5 & 8.65 & 8.04 & 5.99 & 91.4 \\
\hline Signific & & NS & NS & NS & NS & NS & NS & NS & NS \\
\hline \multicolumn{10}{|c|}{ Irrigation $^{2}(\mathrm{I})$} \\
\hline LF & & 7.94 & 6.58 & 5.30 & 88.2 & 8.49 & 7.91 & 5.92 & 91.5 \\
\hline $\mathrm{HF}$ & & 7.96 & 6.70 & 5.22 & 87.9 & 8.50 & 8.08 & 5.92 & 91.4 \\
\hline Signific & & NS & NS & NS & NS & NS & NS & NS & NS \\
\hline \multicolumn{10}{|c|}{ Staking (S) } \\
\hline no & & 7.66 & 6.53 & 5.18 & 87.7 & 8.30 & 7.86 & 5.80 & 91.5 \\
\hline yes & & 8.26 & 6.74 & 5.33 & 88.5 & 8.68 & 8.12 & 6.05 & 91.4 \\
\hline Signific & & $*$ & NS & $*$ & NS & $*$ & $*$ & $* *$ & NS \\
\hline \multicolumn{10}{|c|}{ Interactions $^{\mathrm{y}}$} \\
\hline \multicolumn{10}{|c|}{$\mathrm{N} \times \mathrm{I}$} \\
\hline $\mathrm{N}$ & $\mathrm{I}$ & & & & & & & & \\
\hline 31.5 & $\overline{\mathrm{LF}}$ & 8.40 & 6.74 & 5.33 & 88.5 & 8.31 & 7.86 & 5.87 & 91.6 \\
\hline 31.5 & $\mathrm{HF}$ & 8.05 & 6.77 & 5.24 & 87.8 & 8.36 & 8.05 & 5.86 & 91.5 \\
\hline 63.0 & LF & 8.80 & 6.42 & 5.27 & 88.0 & 8.67 & 7.96 & 5.99 & 91.4 \\
\hline 63.0 & $\mathrm{HF}$ & 7.88 & 6.62 & 5.19 & 88.1 & 8.63 & 8.12 & 5.99 & 91.3 \\
\hline Signi & ance & $*$ & NS & NS & NS & NS & NS & NS & NS \\
\hline \multicolumn{10}{|c|}{$\mathrm{N} \times \mathrm{S}$} \\
\hline $\mathrm{N}$ & $\mathrm{S}$ & & & & & & & & \\
\hline 31.5 & $\overline{\text { no }}$ & 7.89 & 6.58 & 5.17 & 87.8 & 8.23 & 7.75 & 5.74 & 91.7 \\
\hline 31.5 & yes & 8.55 & 6.93 & 5.40 & 88.4 & 8.42 & 8.16 & 5.99 & 91.4 \\
\hline 65.0 & no & 7.42 & 6.48 & 5.19 & 87.5 & 8.37 & 7.98 & 5.87 & 91.4 \\
\hline 65.0 & yes & 7.96 & 6.56 & 5.27 & 88.5 & 8.94 & 8.10 & 6.10 & 91.4 \\
\hline Signi & ance & NS & NS & $*$ & NS & NS & NS & NS & NS \\
\hline \multicolumn{10}{|c|}{$\mathrm{I} \times \mathrm{S}$} \\
\hline I & $\mathrm{S}$ & & & & & & & & \\
\hline$\overline{\mathrm{LF}}$ & $\overline{\text { no }}$ & 8.40 & 6.74 & 5.33 & 88.5 & 8.36 & 7.80 & 5.82 & 91.7 \\
\hline LF & yes & 8.05 & 6.77 & 5.24 & 87.8 & 8.62 & 8.01 & 6.04 & 91.4 \\
\hline $\mathrm{HF}$ & no & 7.50 & 6.42 & 5.27 & 88.0 & 8.24 & 7.96 & 5.78 & 91.4 \\
\hline $\mathrm{HF}$ & yes & 7.88 & 6.62 & 5.19 & 88.1 & 8.75 & 8.24 & 6.06 & 91.5 \\
\hline Signi & ance & NS & $* *$ & NS & NS & NS & NS & NS & NS \\
\hline
\end{tabular}

${ }^{2}$ Irrigation frequency: LF = low frequency; HF = high frequency.

${ }^{\mathrm{y}} \mathrm{N} \times \mathrm{S} \times \mathrm{I}$ interactions were all nonsignificant and are not shown.

Ns, *,** Nonsignificant or significant at $P<0.05$ or 0.01 , respectively.

of pepper (Capsicum annuum L.). Can. J. Plant Sci. 67:315-320.

O'Sullivan, J. 1979. Response of bell pepper to irrigation and nitrogen. Can. J. Plant Sci. 59:1085-1091.

Olsen, J.K., P.J. Lyons, and M.M. Kelly. 1993. Nitrogen uptake and utilization by bell pepper in subtropical Australia. J. Plant Nutr. 16:177193.

Payero, J.O., M.S. Bhangoo, and J.J. Steiner. 1990. Nitrogen fertilizer management practices to enhance seed production by 'Anaheim Chili' peppers. J. Amer. Soc. Hort. Sci. 115:245-251.

Qawasmi, M., M.J. Mohammad, H. Najim, and R. Qubursi. 1999. Response of bell pepper grown inside plastic houses to nitrogen fertigation. Comm. Soil Sci. Plant Anal. 30:2499-2509.

Russo, V.C. 1991. Effects of fertilizer rate, application timing and plant spacing on yield and nutrient content of bell pepper. J. Plant Nutr. 14:10471056.

Rylski, I. and M. Spigelman. 1986. Effect of shading on plant development, yield and fruit quality of sweet pepper grown under conditions of high temperature and radiation. Scientia Hort. 29:3135.

Thomas, J.R. and M.D. Heilman. 1964. Nitrogen and phosphorus content of leaf tissue in relation to sweet pepper yields. Proc. Amer. Soc. Hort. Sci. 85:419-425.
VanDerwerken, J.E. and D. Wilcox-Lee. 1988. Influence of plastic mulch and type and frequency of irrigation on growth and yield of bell pepper. HortScience 23:985-988.

Wells, O.S. and J.B. Loy. 1985. Intensive vegetable production with row covers. HortScience 20:822-826.

Wiedenfield, R.P. 1979. Vegetable utilization of nitrogen from controlled release fertilizers. Texas Agr. Expt. Sta. PR-3589.

Zebarth, B.J., P.A. Bowen, and P.M.A. Toivonen. 1995. Influence of nitrogen fertilization on broccoli yield, nitrogen accumulation and apparent fertilizer-nitrogen recovery. Can. J. Plant Sci. 75:717-725. 